\title{
When the Poison Is the Cure-Healing and Embodiment in Contemporary Śrīvidyā Tantra of the Lalitāmbikā Temple
}

\author{
Maciej Karasinski-Sroka
}

Department of Foreign Languages, Hainan University, Haikou 570228,China; m_karasinsk@hainanu.edu.cn

\begin{abstract}
This paper discusses the healing practices of samayācāra Śrīvidyā, a Hindu Tantric tradition. This study is based on field research conducted in the Śrī Lalitāmbikā temple in Coimbatore, India. The tradition not only advocates inner ritualism, but also focuses on healing practices derived from Tantric sources. By using both emic and etic approaches, this paper attempts to show how the rituals and Śrīvidyā meditative practices became incorporated into this system of healing and well-being. A further aim of this paper is to indicate how various forms of embodiment and healing define the spiritual practice of Lalitāmbikā Śrīvidyā.
\end{abstract}

Keywords: Śrīvidyā; Tantra; healing; embodied knowledge; experience

check for updates

Citation: Karasinski-Sroka, Maciej. 2021. When the Poison Is the Cure-Healing and Embodiment in Contemporary Śrīvidyā Tantra of the Lalitāmbikā Temple. Religions 12: 607 https://doi.org/10.3390/rel12080607

Academic Editor: George Pati

Received: 6 July 2021

Accepted: 30 July 2021

Published: 5 August 2021

Publisher's Note: MDPI stays neutral with regard to jurisdictional claims in published maps and institutional affiliations.

Copyright: (C) 2021 by the author. Licensee MDPI, Basel, Switzerland. This article is an open access article distributed under the terms and conditions of the Creative Commons Attribution (CC BY) license (https:// creativecommons.org/licenses/by/ $4.0 /)$.

\section{Introduction}

Śrīvidyā is a Hindu esoteric (Tantric) tradition centered on the worship of the goddess Tripurasundarī, and her arcane diagram Śrīcakra, which is believed to represent powers of the universe. The main aim of this study is to indicate how the Tantric rituals and meditations of Śrīvidyā have been integrated into the system taught at the Śrī Lalitāmbikā temple, also known as the Samayācāra Śrīvidyā Healing and Wellbeing Centre.

In his study on African religions, Janzen (1992) observes that the distinction between religion and healing is irrelevant from the perspective of the followers of the African cults. Thus, "by entering African religious and therapeutic expression through its own language" Janzen tries to investigate the meaning of healing practices in the context of the tradition. ${ }^{1}$ Similarly, this study here presents Tantric practitioners' views on and definitions of spiritual therapeutics to show the close connections between religion, ritual activity, health, and illness. Hence, this paper argues that the inner ritualism of Tantra and health matters are inextricably interwoven.

This paper focuses on the healing practices ${ }^{2}$ of Śrīvidyā and shows how external rites (bāhya pūjās) have been internalized in the samayācāra lineage of this tradition. Tantric healing consists primarily of invoking selected deities to one's body, blocking or disintegrating negative energies with the power of mantras, and transforming "self-awareness, hitherto confined within the body, to the cosmic awareness that embraces the totality" (Timalsina 2012b). In what follows, I intend to contextualize Tantric healing practices by applying an emic perspective to a living tradition of Śrīvidyā. This study is based on participant observations of the rituals of Śrīvidyā Samayācāra of the Śrī Lalitāmbikā temple in Coimbatore, India. Joining the community and participating in their religious activities-that is, engaging in active participation (Spradley 1980, p. 62)-allowed me to simultaneously observe and experience the documented practices. This insider's perspective on the rites is compared with Śrīvidyā ritualism introduced in the authoritative scriptures of this tradition. Thus, this study addresses the lack of ethnographically informed perspectives on Tantric traditions, while comparing the ethnographic data with orthopraxis known from textual sources. 


\section{2. Śrividyā: A Tantric Tradition of the Goddess Tripurā}

The followers of Śrīvidyā worship a goddess called Tripurasundarī (the Beautiful One of the Three Worlds), Lalitā (the Playful One) or Kāmeśvarī (the Goddess of Erotic Desire). In the older form of this tradition, the goddess was worshipped together with Kāmadeva (the God of Erotic Desire) and a retinue of female spirits (Golovkova 2020). However, in time, this esoteric cult morphed into a complex system of spiritual practices aimed at the realization of non-duality.

The tradition proclaims that the goddess emits and sustains the three worlds of Hindu cosmology (Golovkova 2020). She is also worshipped in three forms. Tripurā's first is her coarse (sthēla) form, that is, her iconographic depiction as a 16-year-old girl, playful and passionate. Her second, subtle (sūkșma) form is that of the śricakra, a ritualistic tool (yantra), which contain her potencies. The nine interlocking triangles of the yantra depict the sequences of the emanation and resorption of reality from and into a central point $(b i n d u)$, which contains them all in an unmanifested form. Śricakra is therefore perceived as a map of reality and a labyrinth of the universe. The third and most subtle (atisūkșma) form of this goddess is her mantra, the Śrī-vidyā (auspicious wisdom), which, in her most secret form, has 16 syllables and is therefore called Ṣoḍaśi. The mantra is traditionally divided into three segments $(k \bar{u} t a)$ that, in turn, are correlated with triple powers and manifestations of the goddess.

According to historians, Śrīvidyā was a cult that developed in Kashmir through incorporating the ritualistic elements of Kashmirian Śaivism (Trika) and later gained popularity in South Indian states (Wallis 2014, p. 105). Golovkova (2019) indicates that Vāmakeśvarìmata and other early texts of Śrīvidyā showed little interest in practices aimed at salvation, and focused instead on empowerment and wish-fulfilling rites. In contrast, the later Yoginihrdaya elaborated on the soteriological meaning of rituals and focused on the internalized, meditative techniques dedicated to the realization of liberation during one's lifetime (jīvanmukti).

In modern South India, there are many Tantric practitioners who consider Śrīvidyā gnosis as the most secret aspect of their revelation (Karasinski 2020). These Tantric groups advocate the Kaula way of conduct (Kaulācāra), with meditations, inner ritual practice

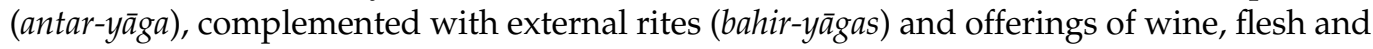
other substances forbidden in orthodox Brahmin traditions (Lawrence 1998, p. 592). However, there are also Śrīvidyā lineages that follow the Samaya way of conduct (Samayācāra). The followers of Samayāaāra abstain from the transgressive offerings and complex ritualism and focus on antar-yāga and yoga (Golovkova 2019). A Vedānta-Tantra syncretism can also be found in the practices of the Śankkarācāryas of Śringeri and the Smārta-Śaiva Brahmins of South India (Wilke 2005). Śrīvidyā can be considered as a vehicle through which Sanskrit scholars of the above stated lineage transformed the cultural norms and integrated South Indian communities of Brahmins (Fisher 2012).

Both Kaula and Samaya Śrīvidyā traditions are found in various parts of India and their spiritual practices have also gained considerable popularity among devotees in other parts of the world. An indication of how widespread the tradition is around the world can be found in Dempsey (2006) study of Śrī Rājarājeśvarī Pịtha in Upstate New York, Bowden (2017) biography of the guru Amrtananda of Andhra Pradesh, and Lidke (2017) monograph on Śrīvidyā in Nepal.

This paper discusses Śrīvidyā in the context of spiritual healing and embodiment. I argue that the tradition of Lalitāmbik $\bar{a}^{3}$ temple focuses on healing practices derived from Tantric sources. This study shows also how various forms of embodiment and healing define the spiritual practice of this tradition.

\section{The Embodiment and Hierophany: The Story of Swami Jagannatha and the Lalitāmbikā Temple}

I first heard about the Lalitāmbikā temple during my field research on Tantric traditions in Kerala in 2012. At that time, I learned from my Tantric informants about a Śrīvidyā 
festival (mahotsava) at the Lalitāmbikā temple of the nearby Coimbatore. The informants introduced the temple as a center of Samayācāra Śrīvidyā that focuses on internal rituals and healing. Hence, I decided to participate in their event to learn more about that tradition and to research their spiritual therapeutics.

The main priest and the founder of the Lalitāmbikā temple introduces himself as Jagannatha Swami. The Swami is a Śrīvidyā guru, an academician, astrologer, and an ardent follower of Advaita Vedānta, a classic non-dualistic school of Indian philosophy. ${ }^{4}$ Reflecting on his spiritual journey, Swami admits:

Vedānta is the central philosophy of Śrīvidyā. Śrīvidyā meditation is like a post graduate course in spirituality. To meditate, one needs to understand that the soul and the divine are one and the same. The soul does not have any centre, it occupies the whole body. The movement of this soul is fundamental to life. The mind, intellect and ego follow its movement. ${ }^{5}$

Swami started his spiritual quest in 1992, when he received a Śrīvidyā initiation from Śrī Balasubrahmanya Sivacarya, a guru from the lineage of a famous Tantric master, Bhāskararāya. During his early days of spiritual training, Jagannatha Swami led the life of a solitary yogi, mendicant, and astrologer. In his search for spiritual knowledge, he embarked on many pilgrimages to holy places in South India. He visited, for instance, Sabarimala, a famous Ayyapan temple in Kerala ${ }^{6}$. Ayyappan is a Keralan celibate deity, a son of two male gods, who gained his legendary powers from ascetic practices (Osella and Osella 2003, p. 729). During his arduous treks to that mountain temple, hidden in the Pathanamthitta forest, Swami received additional spiritual insights into the Śrīvidyā lore from Brahmins and monks who lived there.

Swami dedicated his life to the study of Vedic philosophy and Tantric ritualism. He learned from yogis and academicians. In time, he gained considerable fame as an expertpractitioner and received a doctorate degree in philosophy. In 1995, prompted by divine visions, Swami decided to build a temple for Lalitāmbikā, the Goddess of Śrīvidyā in her form of Universal Mother. In 1997, he received a donation of land and started building the sanctum sanctorum. According to tradition, the place was a meeting ground for ancient sages, who had long since cast away their material bodies and continued to live in their spiritual forms. The land was therefore considered to be a living entity, imbued with spiritual meaning and divine powers. Due to various obstacles, the building process suddenly stopped a year later, in 1998. After consultations and astrological enquiries, it was discovered that the land once belonged to a hermit and devotee of a Hindu god, Śrī Lakșmi Narasiṃha. Thus, the astrologers recommended building a shrine for this deity. Finally, the temple complex was erected with shrines for Lalitā, Mahalakșmī, Sarasvatī, Lakṣmi Narasiṃha and Śiva. The temple construction was completed in three years and was consecrated in the year 2000 .

Interestingly, the story about a guru who receives divine inspiration to erect a temple and restore an ancient sacred site is a common motif in the hagiographies of many Śrīvidyā masters. Thus, for instance, spiritual visions led to another contemporary Śrīvidyā guru, Swami Amrtananda, a former nuclear physicist, leaving his scientific research and retreating into the remote forest of Andhra Pradesh. There, according to his biography, the goddess prompted him to find and rebuild an ancient Tantric temple. The new temple, consecrated in 1994, soon attracted crowds of followers from India and abroad, becoming an important Śrīvidyā center called Devipuram (Bowden 2017). Similarly, another Tantric guru of the Kaula Śrīvidyā path, whom I met in Kannur (Kerala), told me about his discovery of an ancient shrine when he was rebuilding his ancestral temples. He was led to the sacred place by dream visions and divine appearances. Hence, the discovering and rebuilding of an ancient temple appears to be an act of re-establishing the continuity of the Śrīvidyā tradition. These "reconsecrated" holy grounds become places of learning, healing and hierophany, a manifestation of the sacred realities (Eliade 1987, p. 11). Moreover, temples like Lalitāmbikā, were designed according to the visions of gurus and therefore embody their transcendental or spiritual experiences. 


\section{Let the Gods Dwell in My Body: The Scheme of Religious Therapeutics in Śrīvidyā}

Studies on religious therapeutics usually take into consideration the various relations between health, healing, embodiment and spirituality. Here, in line with Fields (1961, pp. 2-3) definition, I use the term the "religious therapeutics" of Śrividyā to designate specific principles and practices of the tradition that focus on healing. ${ }^{7}$ The religious therapeutics in this context include healing practices that are performed to improve both psychophysical and spiritual health. I wish to stress that the Samayācāra Śrīvidyā of Lalitāmbikā is a tradition that defines itself through its orientation toward healing and wellness. Hence, I attempt to examine the tradition from the perspective of its therapeutic impetus and indicate how the concepts of "embodiment" and "healing" function in the spiritual practices of this tradition.

Fields (1961, p. 6) observes that the yogic path deals with psychophysical health but its healing practices are oriented toward liberation understood as the "actualization of unobstructed self-identity, and, consequently, the elimination of suffering". Thus, he indicates two aspects of healing in spiritual traditions: (1) healing as the improvement of physical and psychological health; and (2) liberation as healing in an ultimate sense. In this paper, I discuss both aspects of healing practices in the Samayācāra Lalitāmbikā tradition but stress the importance of liberation as the goal of Śrīvidyā spiritual practice and healing par excellence.

In the words of the Swami, the Śrivvidyā tradition is a "harmonious blend of all paths of spirituality", a samarasa-mārga. In fact, the term can be traced back to the philosophy of Trika Śaivism of Kashmir. According to the Kashmirian Śaiva tradition, when an enlightened yogi realizes the non-duality of the universe, they experience absolute freedom, spontaneity, and an infiniteness of all-pervading consciousness. One of the terms used to describe this state was samarasya, that is, having the same flavor (Muller-Ortega 1997, p. 52). Hence, samarasa mārga can be translated as a path leading to the experience of that state. However, the Swami adds that even though this path leads one to enlightenment, it also improves one's physical and mental health. He insists that Śrīvidyā promises svatantrya, absolute freedom from illusions of duality $(m \bar{a} y \bar{a})$, the very cause of human suffering. In the Samayācāra Śrīvidyā tradition of Lalitāmbikā, the disease is either psycho-somatic or spirito-somatic, and the spiritual advancement eradicates the root cause of the ailment, that is, māya . According to the Swami, the highest, liberating knowledge that grants svatantrya is equivalent to Brahmajñanna (the realization of Brahman) of Vedānta. ${ }^{8}$ Thus, to realize oneness with Brahman, the ultimate reality, one should-to quote Coward (2008, p. 132) - "enter into fully perfected human life of eternal freedom". The spiritual realization is said to cure all the suffering caused by the ephemerality of the material world. Seligman (2010, p. 297), in a study on medical anthropology, observes that suffering may potentially "undermine the coherence of lived selves" and cause "internal conflict, disjuncture, or fragmentation". Conversely, the adepts of Samayācāra Śrīvidyā undergo a Tantra-yoga training to forsake the feeling of disjuncture and to attain the state of divine non-duality. According to the Hindu tradition, this experience of perfect unity with the divine in the midst of apparent (illusory) duality of the world brings about a feeling of "fullness" (pürnatva) (Mann 1984, p. 172).

The Śrīvidyā of Lalitāmbikā is a spiritual school that advocates Vedānta philosophy, but also proposing Tantric methods to access the Brahmajñanna. The adepts are told to approach the divine in a fourfold manner: through the external worship of the idols of Mother Goddesses, the rituals of śrīcakra, kundalinī yoga, and mantra practice. All these acts are interlinked and together constitute the basic syntax of Lalitāmbikā Samayācāra orthopraxy.

Kundalin̄ yoga and Śrīvidyā meditation activate nine cakras ${ }^{9}$, energy centers of the human body that correspond to the enclosures of śricakra. In all the practices, śrīcakra is the main tool and the point of reference. The adepts believe that in the process of invoking gods and goddesses to the bodily cakras and visualizing them as the enclosure (āvarana) of śrīcakra, one's body is deified and empowered with the divine forces. ${ }^{10}$ For the believers, śricakra represents the powers of both microcosm (body) and macrocosm 
(universe). Śrīcakra also functions as a visual representation of the goddess. Conversely, mantras are her sonic forms and the auditory equivalents of śricakra. In what follows, I wish to discuss the spiritual practice of Samayācāra Śrīvidyā and indicate how the abovementioned elements function in the system of healing.

\section{5. Śrīcakra and the Embodied Universe}

As observed by Timalsina (2015, p. 52), Tantric practice relies on creating and manipulating images or visions. Many rituals and meditations require an adept to imagine, create or contemplate a visual form of a deity or symbolic structures like yantras. Śrīcakra of Śrīvidyā, arguably the most famous sacred image of Tantric Hinduism, is a visual representation of the processes of creating and dissolving the universe. It is therefore worshipped as the divine structure of the world. Śricakra consists of nine enclosures identified with mystical powers to be gained and, paradoxically, obstacles that need to be removed through their spiritual practice. (Bafna 2000). The outermost gateways of śricakra take the form of three parallel lines, with its openings called doorways $(d v \bar{a} r a)$. Therefore, a person performing a śrīcakra rite (or meditating upon śrīcakra) is virtually entering the universe of the yantra. Entering into the Śrīcakra can be seen as finding shelter from ailments of the external world, but also leads to the realization of the complexity of the universe and its powers. Lakṣmīdhara, one of the first historical proponents of Samayācāra Śrīvidyā, defines the main goal of Samayācāra as the interior worship of the śrīcakra, a yantra that leads one through its labyrinthine enclosures and at the same time induces the adept's inner energy to travel through bodily cakras: from the lowest mūlädhāra to the thousand-petalled lotus of brāhmanda (Wilke 2012, p. 46) (Figure 1). ${ }^{11}$

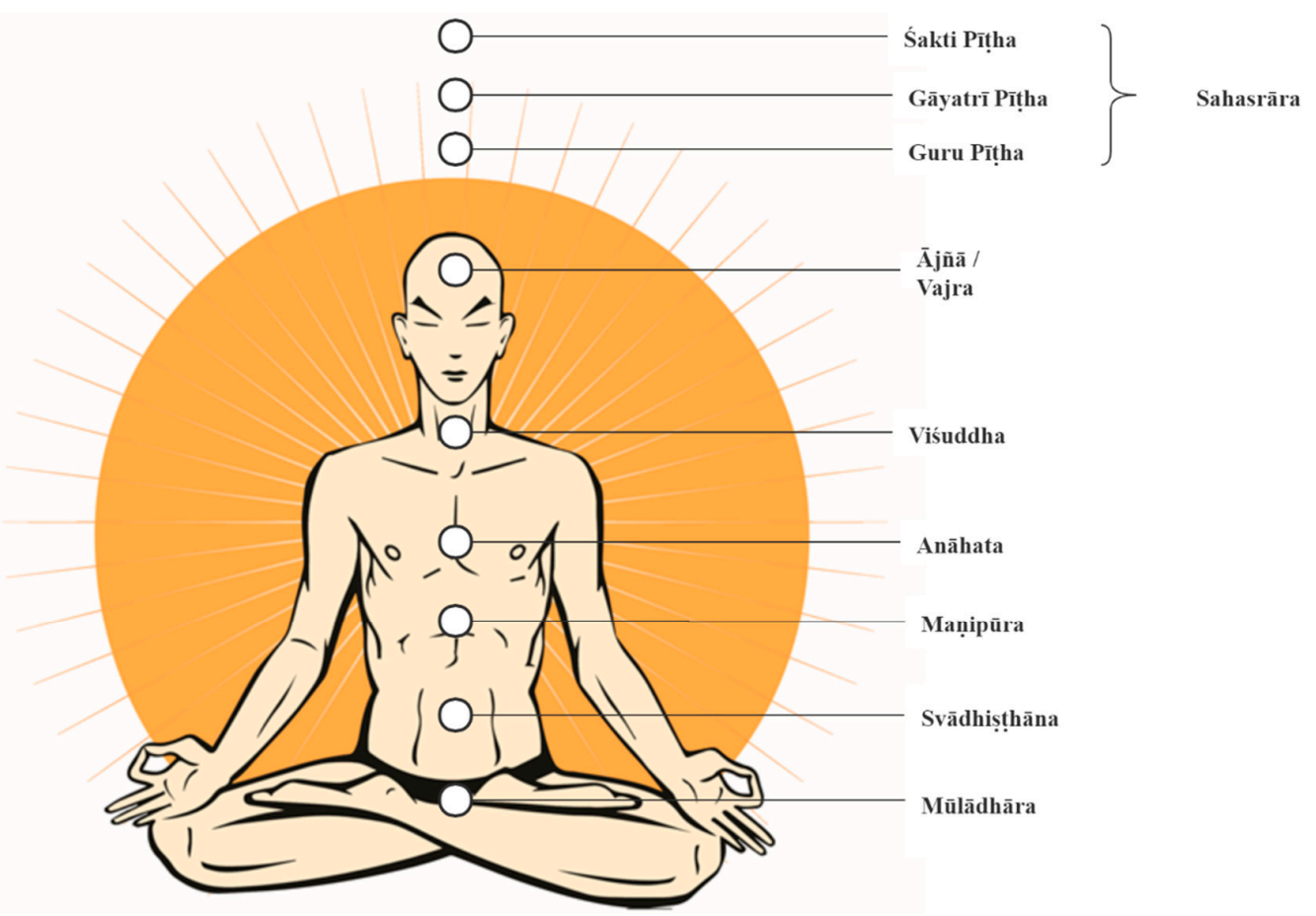

Figure 1. The cakras according to Samayācāra Śrīvidyā of Lalitāmbikā.

In the scriptures of Śrīvidyā (e.g., Varivasyārahasya 2.92), the section on bhüpura is called the Wheel Enchanting the Three Worlds (trayilokyamohanacakra). If śrīcakra is visualized in its three-dimensional form (meru śrīcakra), two more openings can be seen, and this group of six doorways corresponds to six cakras located in the body of the practitioner (Figure 2). Conversely, the inner most cakra, the "Wheel of All Bliss" (Sarvānandamaya cakra) is the final resting place of the soul that finds liberation beyond time and space. Before one can reach that wheel, one needs to pass other enclosures that include Sarvarogahara cakra 
and Sarvarakșäkara cakra, the "Wheel Removing All Diseases" and "Wheel of Complete Protection". In the healing practices of Lalitāmbikā, Sarvarogahara cakra is also mentally removed from śricakra and visualized within one's body or the body of a patient. Afterward, the afflicted parts of the body are mentally cleansed and energized with the powers of the goddesses that inhabit Sarvarogahara cakra. Sarvarakșākara cakra is used in a similar fashion in meditations of protection. Conversely, a person meditating on Sarvānandamaya cakra should visualize the other enclosures of śriccakra, merging and revealing a single reality. Therefore, the journey within śricakra leads an adept through various aspects of protection and healing and ultimately takes them beyond these two.

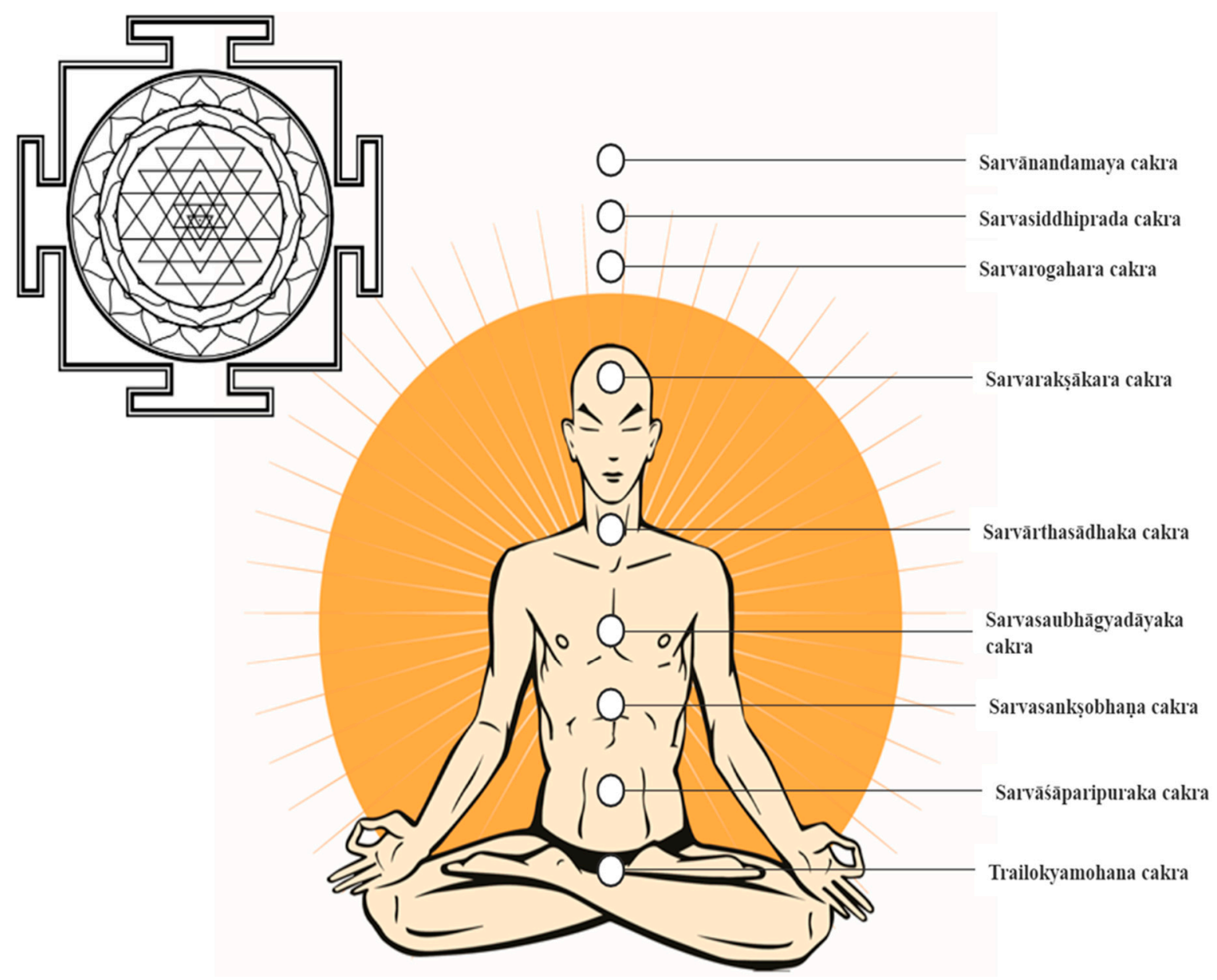

Figure 2. Correlation between the cakras of the human body and the enclosures of Śrīcakra.

Higgins (2018) observes that a labyrinth is "both a symbol of the body and its fragile mysteries, and a gesture of optimism that a corner of the universe can be mastered and given pattern and order by the human mind". Therefore, Śrīcakra can be seen as a labyrinth and tool used by the adepts to reorganize their life. In fact, a modern mystic and yogi, Swami Rama (Rama 2007, pp. 187-94), called śrīcakra a "map of the path of eternal return to inner wholeness and perfection". Additionally, during my research in Uttar Pradesh, I came across yogis initiating adepts into esoteric practices of kundalini yoga. One of the tools used in the initiations was śricakra. When questioned about its use, the yogis vehemently denied any affiliation with Śrīvidyā, but described śrīcakra as a "power tool" capable of channeling the kundalini. ${ }^{12}$

Many concepts represented in śrīcakra are derived from the Kashmirian Śaiva theology that states that the universe is a projection or reflection (pratibimba) of the self-image of the divine (İśvara-pratyabhijñ̄a-kārikā, 2.4.19). Thus, Śrīcakra is both identical to the divine consciousness and different from it; it is both the very form of reality (rupa) and its most 
ideal reflection (bimba). An adept who identifies with Śrīcakra is therefore the reflection and the embodiment of reality.

The ritual of śricakra (usually referred to as navāvarana pūjō -a "ritual of nine enclosures") is a composite procedure for initiated devotees that comprises several lesser rites honoring enclosures of the diagram-intricate enfilades of rooms inhabited by goddesses and their powers. ${ }^{13}$ The long litanies of the divine names are inscribed in the labyrinth of śrīcakra - they form a kind of power-cipher that an adept must decode and internalize. This can be performed in two distinct manners: srstit (according to the principle of creation) in Samayācāra or saimhāra (a way of dissolution) in Kaula. These two differ in their starting point of the adoration: srst $i$ is pursued from the inner part to the outer regions, while saminara is pursued from the outermost enclosures to the central bindu (Brooks 1992, p. 25). In this respect, it is worth quoting Brooks (1992, p. 151), who states that: "the ritual worship of śricakra is actually a series of smaller rites that are individually distinguished and combined into a larger pattern of meaning and activity". The rites consist of invocations of the retinues of goddesses and divine powers located in the enclosures of śrīcakra. During navāuarana pūjā in the Lalitāmbikā temple, the invoked divinities are honored with flowers and food offerings, praised with eulogies in both Sanskrit and Tamil, and visualized as coexisting in both śrícakra and the body of an adept performing or participating in the rite. As per the testimony of senior students of the Lalitāmbikā temple, an adept's intimate relationship with the deities of śricakra is brought about through the repetition of a series of reverential acts and reiterations of mantras and accompanying ritual gestures.

In the words of Lidke (2016), śrīcakra has a dyadic nature: it is a visual emanation of divinity and a sonic field that constructs the acoustic body of the goddess. Thus, the key element of the ritual is a process of linking these fields by ritually constructing and worshipping śrīcakra in its physical form and in one's consciousness. The śrīcakra ritual, whether external or mental, is therefore a play between a pure internalized consciousness and the manifested reality.

As stated by the practitioners of Lalitāmbikā Samayācāra, the śrīcakra ritual leads to empowerment, rejuvenation and liberation. Nonetheless, according to the Swami words, the spiritual progress would not be possible without the blessings of guruparampara $\bar{a}$, the tradition of gurus into which an adept is initiated at the start of their spiritual practice. In the case of Samayācāra Śrīvidyā, the guruparamparā is a lineage of teachers from Bhāskararāya (c. 1728-50) up to the Swami Jagannatha. ${ }^{14}$ The guruparamparā is worshipped in śrīcakra and honored before any ritual practice can commence.

Bhāskararāya Makhin (ca. 1690-1785 CE) is known as a Tantric master, polymath and prolific commentator of Sanskrit works. He is generally considered to be the undisputed authority on the Śrīvidyā, especially in South India. His commentaries touch upon Śrīvidyā and Vedānta philosophies, but also shed light on various aspects of the Śrividyā ritualism. Interestingly, in his works, he quotes and paraphrases Vedic and Tantric sources that he interprets in light of Vedāntic non-dualism. His synthesis of Vedic and Tantric theologies opens new dimensions of meanings of Śrīvidyā doctrines. However, as Khanna (2016) rightly points out, while Bhāskararāya provided insight into the inner ritualism and meditation of Śrīvidyā, the complex internalization of śrīcakra and spiritual exercises that connect the yantra with the cakras of the subtle body differ from one lineage to another and have various variants advocated by their respective gurus. In the following paragraphs, I wish to indicate how the aforementioned spiritual practices were adapted by the Lalitāmbikā Samayācāra tradition.

\section{Healing through Meditation and the Spiritual Reconstruction of the Body}

According to the Lalitāmbikā Samayācāra tradition, an initiated adept can perform Śrīcakra rites only after completing a series of preliminary practices that include mantrachanting routines and kundalini meditations. These practices are aimed to enhance their physical, mental and spiritual health. Many Tantric practitioner believe that kundalini yoga is "a therapy to treat the immediate bodily and mental distresses of the individual" and 
lead to the ultimate healing in a form of self-realization" (Farah and Khalsa 2015, p. 395). The kundalin̄̄ yoga of the Samayācāra system comprises the physical practice of postures (āsana), breath control, mantra chanting, and meditation. As in other schools of kundalin $\bar{\imath}$ yoga, the adepts learn various forms of locks (bandhas) and relaxation techniques that are aimed at regulating the flow of internal energy. The meditation is combined with a mantra practice: adepts invoke divine couples-male and female deities-into the cakras of their body and visualize the flow of internal energy (kundalinī $).{ }^{15}$ In fact, the mūlādhāra has Ganapati as its sole patron but higher cakras are inhabited by manifestations of Brahma, Viṣnu and Siva with their consorts. Weiss (2009, p. 130) notes that Siddha adepts he interviewed in Tamilnadu meditated on Rudra and Parvati as dwelling in the anāhata cakra and invoked Sadaśiva and Manōnmanī into the ājñ $\bar{a}$ cakra. Interestingly, the same deities are praised and invoked in those cakras by the adepts of the Samayācāra of the Lalitāmbikā temple. The highest cakra called sahasrāra (Thousand-Petalled Lotus) ${ }^{16}$ is subdivided into the guru domain, the domain of gayatri and the domain of Tripura-sundari in her form of Śakti-the energy of the universe. The adepts visualize the divinities in their cakras and, by chanting mantras and yogic breath control exercises (prānāyāma), propel

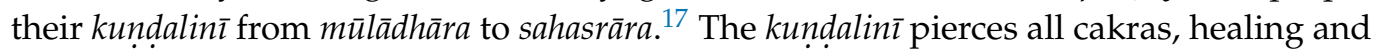
energizing them, and removing the energy blocks. These blockages are apparently caused by stress, emotional or physical traumas and aggravated by various factors such as toxins and poor living conditions. The inner energy blocks, according to the practitioners of the Lalitāmbikā temple, may cause a gradual deterioration of health and thus the Samayācāra meditation is a tool to reprogram the human body to heal itself. During the last stage of Samayācāra meditation, an adept is instructed to mentally unify all the cakras of their body and meditate on the divine presence in the $\bar{a} j \tilde{n} \bar{a}$ (vajra) cakra, while chanting a mūla mantra, a sacred formula they received from their guru.

Similar spiritual exercises are mentioned in Bhāskararāya's commentary on Lalitāsahasranama (1919: verse 52), the famous eulogy (stotra) praising 1000 epithets of the Lalitā goddess. ${ }^{18}$ The author of this text briefly states that when an initiated adept starts the practice of mahāvedha, by the grace of the preceptor, kundalini rises from the mūlädhāra and enters the manipurra cakra. There, the aspirant should venerate her with eulogies and mantras. In the process, the kundalini power will move to the anāhata cakra and later to the viśuddha cakra, where one should visualize her adored with the luster of the moon. Then, with subsequent spiritual exercises, the adept should elevate the kundalini śakti to their $\bar{a} j \tilde{j} \bar{a}$ cakra and to the thousand-petalled lotus. The finale of the meditation is reached when the adept visualizes śrícakra and focuses on its central point, while chanting the mūla mantra. In this state, the adept is said to experience the unity of the whole universe. The said mūla mantra, to be chanted in their final stage of meditation, is correlated with an adept's level of spiritual advancement. The spiritual progress of the adepts is marked by series of initiations when they are given new mantras to chant and use in their meditations. After formal initiation, one is required to follow specific directions from the guru, and these directions underscore the importance of orthopraxis: performing the appropriate mantra at the appropriate time and place. This spiritual journey starts with a mantra known as Śrīvidyā tritari (aim-hrīm-śrìm). The three syllables are traditionally ascribed to three goddesses: aim-Sarasvatī, hrìm-Durgā, and śrīm-Lakșmī. Thus, the repetition of the mantra is supposed to attract good fortune (Lakșmī), destroy the obstacles (Durgā), and bring wisdom (Sarasvatī). The hrìm mantra, the Śakti-power syllable, is also used in healing and purification rites. ${ }^{19}$ To give just one example, the adepts learn a technique of visualizing problems or negative thoughts in the sahasrāra cakra and dissolving them with a help of the Durgā mantra. Thus, as described by Padoux (2017, p. 118), the mantra practice of Śrividyā is in fact "a yogic mental and bodily action" that renders the body divine and regulates the internal powers.

Other practices of Samayācāra also involve manifold nyāsas - the projection of mantras onto the human body. According to the Swami, nyāsas are performed to connect the macrocosm of the universe with the microcosm of the practitioner's body. Apart from 
the $n y \bar{a} s a s$, adepts utilize yogic breath techniques and visualizations to purify their bodies. Indeed, the purification process is conducted through elaborate visualizations of burning, washing and recreating the body. ${ }^{20}$ This imaginary destruction and recreation of the body is performed, for instance, during the Śrīcakra ritual and is conducted with specific mantras found in the authoritative scriptures of Śrīvidyā, for instance in Paraśurāma Kalpasūtra (7.6).

During this practice, an adept should mentally chant: "om aim hrīm śrìm mūlaśṛngāṭakāt suṣumnāpathena jīvaśivam paramaśivapade yojayāmi svāhā".

Afterward, they should inhale through the left nostril and, while doing so, visualize their spiritual self (jīvātman) in the mülādhāra cakra traveling through sușumna nādi to the sahasrāra cakra, to merge there with the divine consciousness. Then, the adept should exhale through the right nostril.

The adept should subsequently chant a mantra "om aim hrì̀m śrìm yam samkoca śarīram śosaya soșaya svāha" to mentally dry and wither their body. Then, with the mantra "om aim hrìm śrìm ram samkośa śarìram daha daha paca paca svāha", the body is mentally burnt and turned into ashes. Afterward, the adept should chant "om aim hrìm śrìm vaín paramaśivāmrtaì varṣaya varṣaya svāha" and visualize the divine nectar (amṛta), an elixir of immortality, being sprinkled over the ashes. With the blessing of the nectar and the power of mantra "om aim hrìm śrìm laì śàmbhava śarìraì utpādaya utpādaya svāha", the ashes are transformed into a new, deified body called Sāmbhava. Finally, the adept should utter the hamsa mantra to transfer the divine consciousness into their new body. ${ }^{21}$

This elaborate process of purification is also simplified in a form of daily meditations where the mantras are skipped, and the procedures are performed entirely with visualizations. As stated by Timalsina (2012b), the body in Tantric traditions "defies the oppositional boundaries of 'outside' and 'inside', and 'subject' and 'object'". Hence, healing is a process that goes beyond physicality and recreates spiritual, mantra-based sheaths of the body. One can also say that Samayācāra Śrīvidyā of the Lalitāmbikā temple promotes a ritual paradigm that endorses several forms of embodiments and healing methods. The temple itself is a sacred structure that embodies a tradition of sages and goddesses, with Lalitã as the main deity. The gurus, sages and divinities protect the adepts from outside and from within, when visualized as sacred powers in the bodies of adepts. The deities of śrīcakra and their energies and powers are internalized during meditative exercises and invoked through mantric incantations. Finally, the body is recreated, divinized, and revitalized through the power of kundalini.

All these practices are considered means of spiritual transformation and the realization of non-duality. Through internal rituals and yogic exercises, one is supposed to reach a state of union with the divine that grants ultimate protection and heals all ailments. Therefore, Śrīvidyā adepts see the body not only as a physical and spiritual entity, but also as a "system of possibilities" (Timalsina 2015, p. 73) and a vehicle for spiritual journey.

\section{The Aims of the Spiritual Journey: Embracing Immanence and Transcendence}

In Śrīvidyā, as in the Tantric traditions of Kashmirian Śaivism, the self (aham) refers to the absolute I-consciousness that embraces the totality, and which, as described by Timalsina (2020, p. 767), "immanently encloses all individualities within its embrace". Conversely, the Samayācāra Śrīvidyā of Lalitāmbikā defines the spiritual practice as a quest for self-discovery and the realization of the transience of worldly powers. Discussing the yoga and bhakti of South India, Shulman (1991, p. 56) gives an example of a poet, Tāyumānavar, who approached a guru named Monakuru and begged him to accept him as a student. Monakuru offered to teach the poet yogic methods of acquisition of esoteric powers and share with him his alchemical wisdom. However, Tāyumānavar declined the offer by saying that none of the supernatural powers are equal to overcoming one's own mind and attaining inner peace. In his poetic stanzas, Tāyumānavar addresses this inner tranquility and projects it as a deity who embodies knowledge and bliss. A similar attitude can be found among many modern practitioners of Samayācāra, who focus on liberation and achieving peace and spiritual realization, rather than gaining supernatural powers. 
In one of the classes conducted during the annual Navaratri Spiritual Workshop in 2012, Swami concluded his lecture by saying:

Some people may think that if you practice Śrīvidyā nothing bad will happen to you. It is not true: good things and bad things may come, but with the grace of the goddess nothing will affect you.

Thus, the Śrīvidyā practice is understood here as a spiritual path of healing and protection: nothing will disturb or hurt an adept who considers themselves as a spiritual being that cannot be afflicted by disease or trauma. This is reflected in yet another story told by the Swami. As the story goes, one of the Swami's disciples abandoned his spiritual practice and stopped chanting mantras. However, the man eventually returned to Swami, repentant, asking for forgiveness and re-initiation. Swami replied: "I gave the mantra to your Ätman [spiritual self] and this spiritual self will never stop repeating it". The man was afterward advised to chant the mantra "in unison with his spiritual self". Thus reassured, he started his spiritual practice anew and, according to his testimony, experienced bliss and peace while chanting the mantra. This example also confirms what Timalsina (2012a, p. 71) observed about Tantric cults in general: these traditions advocate a range of spiritual practices by embracing simultaneous immanence and transcendence (viśvottìrnaviśvamayatā). In other words, one is encouraged to use meditation and other esoteric techniques to realize one's spiritual self and recognize the divine as both an independent reality and contained within the world of human experience.

Nevertheless, the spiritual practices of the Lalitāmbikā tradition are in many ways connected with concepts of health and healing. In what follows, I wish to describe and interpret the rituals taught at the Lalitāmbikā temple during the Navaratri Spiritual Workshop and indicate how those spiritual routines were integrated into the Samayācāra system of healing and wellness.

\section{Spiritual Healing and Embodied Trust: Reminiscences of the Navaratri Spiritual (Śrîvidyā) Workshop 2012 at the Lalitāmbikā temple}

8.1. The Temple: April 2012

It is my first foray into the Anunavi Hills, a long bus ride from Coimbatore town. Around me, the forest and green paddy fields stretch uphill toward the Lalitāmbikā temple.

I find Swami waiting for me in the shade of the temple's colorful gopura (ornate tower). The tower blushes in the setting sun, its layers lined up with brightly-colored, carved goddesses (Figure 3). Nestled on the foothills of picturesque Anuvavi, the temple's main goddess Lalitā is considered by the local devotees as an embodiment of Mother Nature. The goddess is worshipped with a retinue of other deities that Swami indicates, as we stroll together toward the main temple hall: Ganapati, Aștalakșmī (Eight Manifestations of Goddess of Fortune), Hanumān, Sarasvatī, Navagrahas (Nine Heavenly Bodies), Subrahmaṇyā, Viṣnu, Durgā, Kāla Bhairava, Sai Baba of Shirdi, Kāmeśvara and Maha Lakṣmī.

In the eastern corner of the temple, a couple of ghee-lamps burn for Laksmī-Narasimha, the guardian deity of the sacred place. There, the pilgrims entering the temple lean precariously to leave offerings and pay obeisance. Every day, each idol will be draped with garlands to the accompaniment of prayers in Sanskrit and Tamil. Every morning, the deities are bathed, appeased with offerings and sent to sleep at dusk with lullaby-like chants. ${ }^{22}$ The structure of the temple complex can also be read in terms of safety and revitalization: the divine beings are guardians of the devotees and manifestations of the spiritual power that underlies all ritual activities. 


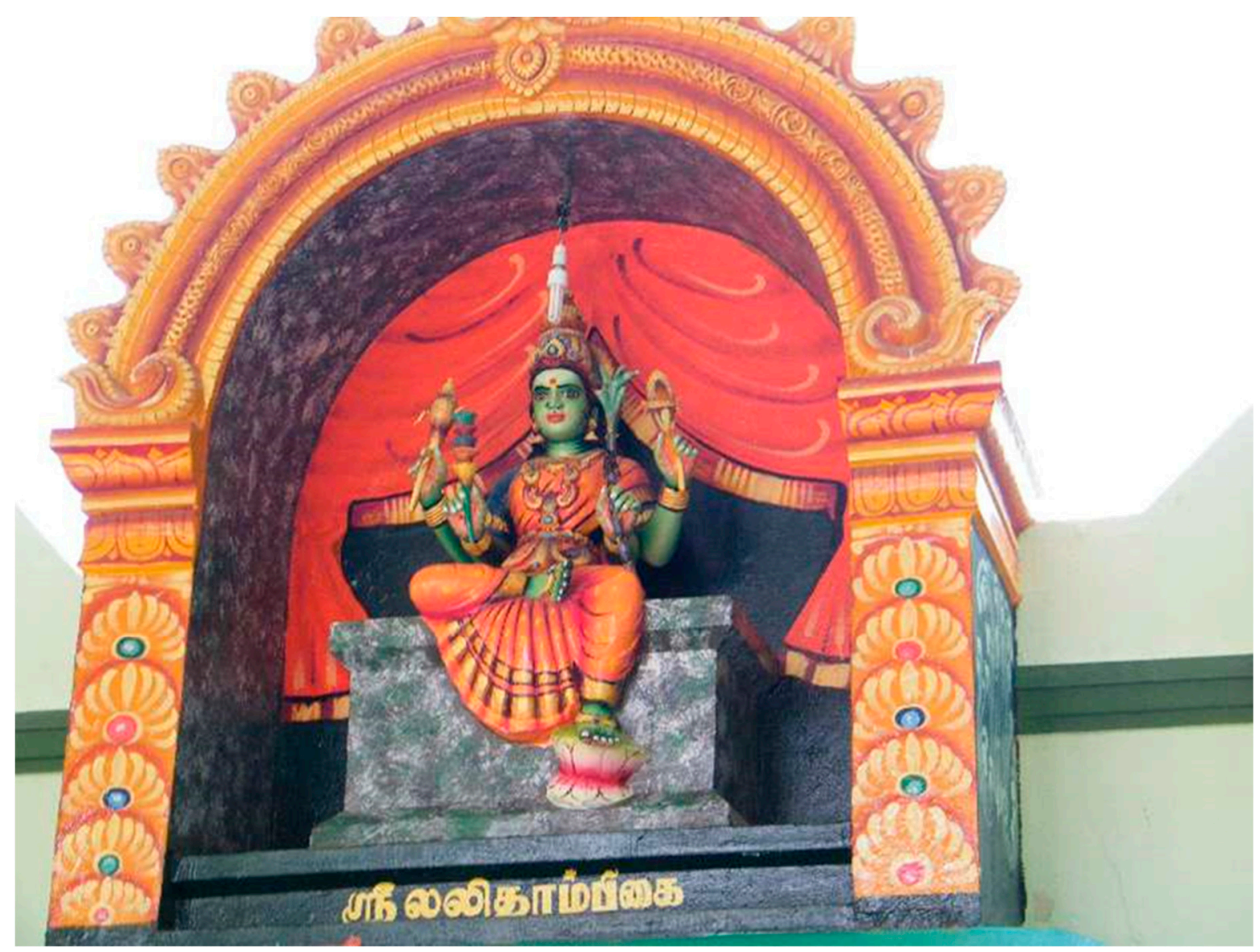

Figure 3. An image of the goddess Lalitāmbikā, Lalitāmbikā temple, Coimbatore.

As I talk with Swami, the gate clinks open, and a group of dhoti-clad disciples approach us. They move warily, whispering about the protective energy of the aisles. I soon notice that the temple activities, and participation in rituals and learning sessions effectively bond the students. One could say that the structure of the spiritual training also contributes to the mental well-being of the participants, by organizing their routines and promoting social interaction. Coming from various parts of India, they arrive with the common purpose of finding their spiritual life. They are spiritual seekers from all walks of life: university students, teachers, and businesspeople. There are men and women from Tamilnadu, Andhra Pradesh, Kerala and North Indian states. Many of them had tried various forms of spiritual practices, some had never meditated before. They came with a belief that their life can be transformed, their longings fulfilled, and spiritual questions finally answered. There are no admission requirements, but the new adepts are asked to strictly follow the guru's instructions and participate in all daily rituals. The next day, dressed in a white dhoti, I join the adepts in their daily routines.

\subsection{Navaratri Mahotsava and the "Spiritual Boot Camp"}

In the sanctum sanctorum of the temple, the śrīcakra is installed in its three-dimensional form of Maha Meru (Figure 4) (Baumer 1994, p. 129) at the feet of Goddess Śrī Lalitāmbikā. Here, devotees and adepts are encouraged to perform abhiṣeka (unction) for the Maha Meru themselves. The abhiseeka is believed to bring blessing and prosperity to one's life, as it attracts the energies of retinues of deities installed in this pyramidal structure. ${ }^{23}$ Apart from Śrīvidyā rituals, the temple has other annual and monthly observances. There are two main festivals of the temple-Navarātri and Caitra Pūrṇimā in April. The Śrī Kāmeśvara Pradoșa ritual is performed bimonthly, on the thirteenth day of every fortnight, according to the Hindu calendar (Van Skyhawk 2008, p. 357). During these times, Siva is worshipped in 
his form of Kāmeśvara and the rituals, performed with an abhișeka of 108 shells, is believed to free the devotees from their sins and remove financial problems. The Navarātri festival is celebrated en masse annually in many countries of South Asia. As the name indicates, the festival lasts for nine consecutive nights and ends with the so-called Tenth day of Victory (Vijayadaśam $\bar{\imath}$ ). Navarātri celebrations take place worldwide, wherever South Asians settle. Most Navarātri festivals are celebrated in the autumn month of Áśvina (September to October). In South India, the main theme of the festival is the victory of the Goddess over demons and consequently the triumph of Good over Evil (Simmons and Sen 2018, p. 1).

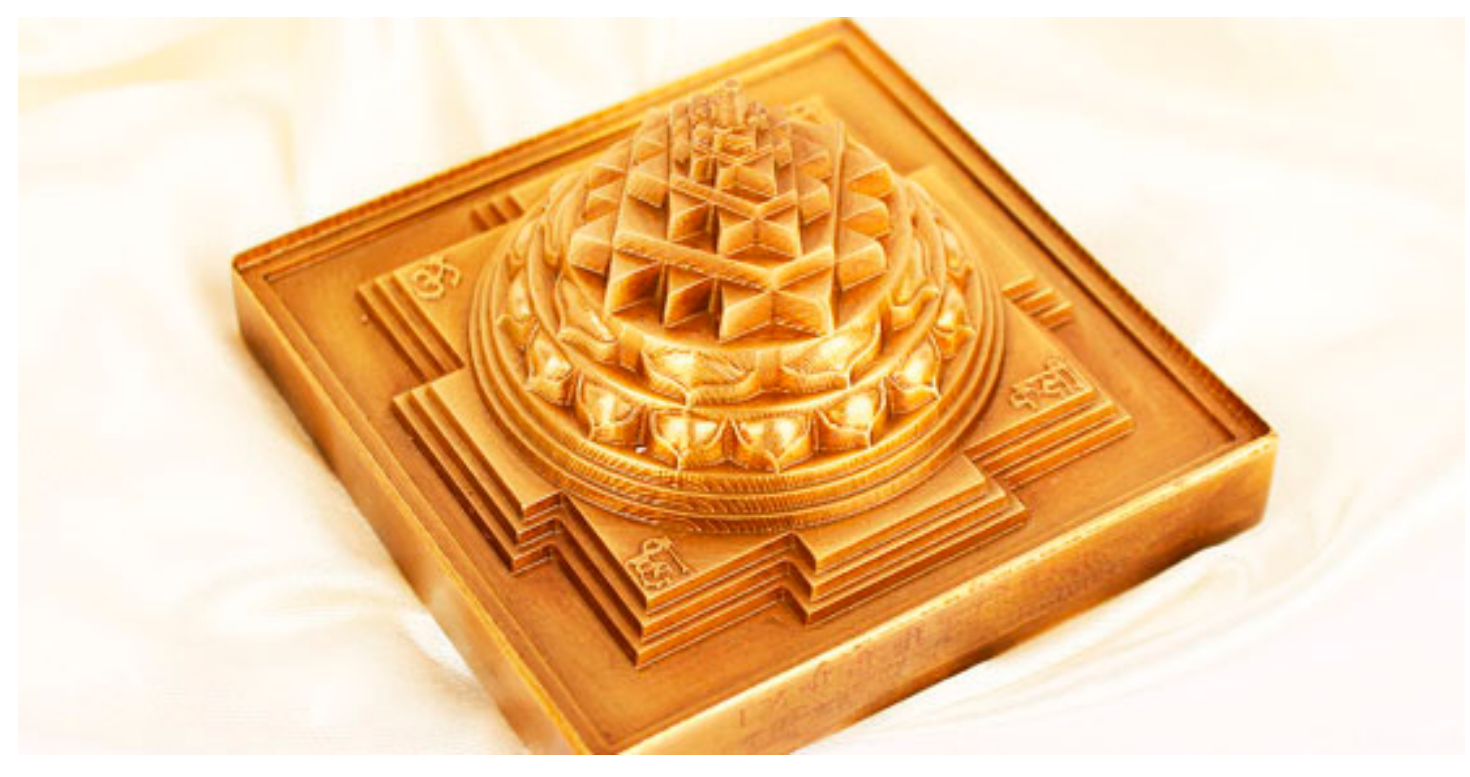

Figure 4. Śrīcakra Meru, https: / /www.srilalithambika.org/poojas.php (accessed on 5 July 2021).

In 2012, the Tantric Navarātri Mahotsava was also the time of the first Śrīvidyā training camp organized by Swami for a group of new disciples. Tulasi (2018, p. 80), in his study on aesthetics of Hindu rituals, observes that aesthetic experience (anubhava) is the basis and the hinge of existence in the life of a devotee. Sanskrit root bhu means to be or to exist and thus its derivate anubhava can be understood as an existential and epistemological experience. Anubhava is also a key term for understanding the practices of the Lalitāmbikā temple. Each day of the training camp was marked by several events-morning sun meditation, fire oblations, śrīcakra rituals, and meditations. The usual daily routine was as follows:

$6.00 \mathrm{am}$ : Sun meditation and homa (fire rituals).

7.30 am: breakfast.

9.00 am: morning meditations and lectures (in English and Tamil) on Śrīvidyā theology. 12.00 midday: lunch.

2.00 pm: solitary meditations, lectures on Śrīcakra and goddesses of the traditions.

$4.00 \mathrm{pm}$ : chanting of eulogies; satsang (spiritual discourses).

Evening: śrīcakra rituals.

These practices were supposed to open the adepts to new ways of experiencing the divine. In addition, the Swami conducted lectures on Tantric eulogies (e.g., Lalitāsahasranama stotra) and the significance of śrīcakra. Many sessions ended with participants sharing their spiritual experiences or asking Swami about the meaning of their visions. Soon, one could virtually feel the trepidation and longing of other adepts to have a transcendental experience, or at least a glimpse of the spiritual reality.

At the end of the day, the tensions were temporarily calmed with the Swami's consoling words and his insistence on emptying one's mind in meditation. The remark was not meant to douse the flames of the neophytes' enthusiasm; Swami insisted that meditation should lead to a spontaneous manifestation of the divine within. He told the students that 
meditation should just "happen", and that divine grace is showered on everyone, so there is no need to be anxious. Still, experience of the divine was something that all the devotees secretly wished for.

Each morning, the training began early with a Sun meditation and mantra chanting on the edge of a forest clearing behind the temple. However, even before the sunrise, the temple grounds were humming with life, with morning ablutions, prayers and the preparation of homas (fire offerings). The adepts were asked to meditate in the morning facing east and, in the evening, facing west, to correlate their thoughts with the journey of the Sun. Swami explained the custom by stating that the Sun is god's image that is visible to everyone, and that every living being receives its blessing. ${ }^{24}$ The Sun meditation included a chant of a gāyatrī mantra for the Sun god, called here Bhāskara:

ori bhāskarāya vidmahe |
mahādyutikarāya dhīmahi ।
tanno ādityah pracodayāt । ।

On the third day, as usual, the Sun mantra chanting started at $6.00 \mathrm{am}$, when the meditation ground reddened with pre-dawn light. We were already in a meditative state, sitting cross-legged with eyes half-shut and bodies erect. Suddenly, we all saw a small dog approaching the meditation ground. The mutt slowly turned around, as if monitoring the practitioners, and then sat down on its hind legs. A minute later, it started to growl, visibly imitating the sonorous chanting of mantras. As the chanting continued, the dog also proceeded with the mantric growling, modelling its voice according to the changes in the group recitation. The meditation ended with a minute's silence, during which the dog also stopped its growling. The incident was later commented on by everyone: the dog and people chanting in unison was accepted as an undeniable proof of the mantras' divine potency. The Swami, discussing the "dog's chant", as it was later referred to, added that Tripurā is herself Mātṛkadevi: she embodies all sounds and words. ${ }^{25}$ Hence, the goddess was also praised as Parā Vāc, the Supreme Speech (Reich 2020). Interestingly, the Sanskrit word Mātrka means both a sound or phoneme and mother. In this respect, it is worth relating another incident that happened during the training camp. After one of the afternoon meditations, two adepts quarreled about the correct pronunciation of a particular mantra. The one accused of mispronouncing the formula angrily argued back: "The Goddess is my mother! A mother wouldn't get angry with her child for misarticulating a word". ${ }^{26}$ Indeed, many adepts I met in the temple considered devotion to and intimate connection with the divine as more important than the perfect articulation of mantras. They also believed that the child-like attitude toward the goddess entails surrender to the divine will and thus eliminates anxiety, insecurity and stress-related conditions.

Moreover, all the statements of the guru (not just their mantras) were believed to have divine potency. Indeed, Swami declared that meditation in the presence of a guru, or even listening to their voice carefully, takes an adept to higher spiritual levels and brings mental peace, harmony and balance into their life. It was a reassuring message for those practitioners who were afraid that the inner energy kundalini, awakened through meditation, might negatively impact their life and health. Such concerns were voiced by several new students. Similarly, some were afraid of the potency of śrīcakra. In fact, in many Tantric temples and family traditions of Kerala and Tamilnadu, I have noticed śrīcakras being honored with flower offerings but not worshipped in a sequence prescribed in ritual handbooks. This can be explained in two ways. First, Śrīcakra rites require the initiation of the Śrīvidyā mantra from a qualified guru. Second, and more importantly, there is a widespread opinion among the devotees that even a minor mistake in a śrícakra ritual may cause serious spiritual problems. The latter taboo is invariably related to the belief that Śrīcakra is an energy tool inhabited by divine potencies, and therefore needs to be treated with reverence and according to the rules put forward by the lineages of masters.

The process of internalizing the śrīcakra practice can be understood as the domestication of the divine energies. The presence of the spiritual guides in human and spiritual 
forms implies security and supervision. According to the tenets of the tradition, the guru, goddess, her mantra and yantra are ultimately the same. Thus, the presence of the guru is considered divine, and is likewise an embodiment of the goddess's powers. Additionally, the predominant image of the goddess of this tradition is one of a Universal Mother guiding and protecting the adepts in the same manner as the guru. In this respect, it is worth noting that adepts undergoing training at the Lalitāmbikā temple were asked to repeat the following affirmation daily: "The goddess Śrī Lalitāmbikā exists inside me, hence no disease can attack me. My body is lying on the lap of the Mother Goddess, there is no pain and no symptoms of any illness". Thus, the above-mentioned practices can be interpreted in relation to the concept of "embodied trust", that is, trusting God's will with ones' physical body (Kiil and Salamonsen 2013, p. 487). This, in turn, points to the traditional definition of the Sanskrit term "Tantra", which relates it to the noun "tanu", meaning body. Thus, according to Tantric tradition, a person needs to activate and use the potencies of their own body to achieve their spiritual goals. The followers of Lalitāmbikā Śrividyā were also convinced that, through the proper use of one's body (in mediation and yoga), it is possible to find health, security and freedom. As explained by the Swami, health comes first as a prerequisite for further spiritual development. Health, in this tradition, is cared about in multiple ways: the programs are aimed at the betterment of physical, mental and spiritual conditions. While the meditative sessions and śricakra rites connected adepts with the tradition and were a means of pacifying their tensions, the fire offerings were performed early in the morning to energize the adepts and to connect them with the elemental forces. Interestingly, the busy schedule of rites and meditations included a weekly voluntary consultation with an Āyurvedic doctor. Therefore, the adepts were not only offered spiritual tools for self-development and healing, but they were also diagnosed in several ways. The Âyurvedic doctor monitored the physical condition of the adepts and the Swami insisted on preparing and checking everyone's astrological charts. Anyone found to have any astrological problems was instructed to perform rites of purification or to meditate on the Navagrahas (Nine Heavenly Bodies). According to Swami's understanding, even if one strives for a balanced life, Rāhu, the north lunar node, along with Ketu, a non-material celestial entity responsible for eclipses, disturbs human life. ${ }^{27}$ The Śrīvidyā meditation was said to nullify the astrological influences of Rāhu-Ketu and re-establish one on a path toward balanced life. The adepts I interviewed after the camp acknowledged that the spiritual exercises they learned allowed them to alleviate pain and to some extent heal their bodies. Gautam, a Tantric practitioner who has studied under Swami since 2013, explains that the Śrīvidyā meditation helped him not only with his spiritual quests, but also with physical problems:

The [Śrīvidyā] practice helps us achieve material enjoyment (bhoga) and liberation (mokșa). This is an all-inclusive sādhanā [spiritual practice], it's not life denying. In my case, I have seen a tremendous change in my inner chemistry and perception, learnt to heal myself as well as others. I have healed many ailments like pneumonia, ovarian cysts and depression, problems related to mind and body. It works extremely fast.

Thus, it could be said that the Lalitāmbikā Śrīvidyā center tailored the Tantric practices, creating a system of health-oriented practices and diagnosis. The adepts not only meditated on internal energy but were encouraged to visualize it being shared with those who need help.

\subsection{Body, Cakras and Spiritual Embodiment}

According to Ulland (2012, p. 101), the term "embodied spirituality" refers to spiritual practices and traditions in which the body is a fundamental tool for spiritual development. This is true for Samayācāra Śrīvidyā, where the body plays a significant role: bodily energy centers are identified with deities and yantras and divinized with mantras. In fact, the correlation of mantras, deities, yantras and the aspirant's body is essential in all Tantric 
traditions (Timalsina 2012a). In the tradition of Lalitāmbikā, the body is considered the abode of the goddess and the goddess herself.

The adepts of the Navaratri camp learned that the Lalitāmbika tradition accepts the six cakras known from the majority of yoga sources, but the top one, the sahasrāra cakra, is divided into three layers called "seats" (pītha): guru-pītha, gāyatrī pịtha and śrìvidyā-pītha. The sahasrāra is unique by being an energetic plane located beyond the physical body (Śivasamhitā 2007, verse 5.191-2). The plane is where people can connect with the tradition and the divine. While the whole tradition of gurus is meditated upon in guru-pitha, an adept reconnects with the goddess through gāyatri mantra practice, while concentrating on gāyatrī pit tha, and achieves enlightenment by uniting with the goddess in śrividya-pit ha (Figure 1). The three pitthas also symbolize the spiritual identity of guru, goddess and mantras (Varivasyārahasya 2.101). ${ }^{28}$

In the Lalitāmbikā tradition, the system of bodily cakras also correlates with dhātus (basic tissue elements). According to Āyurveda, the body is supposed to have seven dhātus, each derived from the one preceding it in the following sequence: rasa (chyle or extract of nutriment), blood, flesh, fat, bone, marrow, and ova or semen (Fields 1961, p. 43). As explained by Swami:

All the elements relate to the cakras from miūlädhāra to $\bar{a} j \tilde{n} \bar{a}$. When we chant the müla mantra (main formula) related to the cakras and do the tapas (asceticism), the five elements get strengthened and the immunity level increases. The body, which is composed of five elements, is ruled by seven dhätus that are again linked with the cakras, and the seminal fluids are the divine secrets that should be transformed into the elixir of immortality in the sahasrāra cakra.

Thus, the Śrivvidyā practices are integrated with a system of natural medicine of the Āyurveda and Siddha provenance. ${ }^{29}$ In fact, the temple cooperates with Āyurvedic doctors to develop treatments for elderly people. The teaching of the Lalitāmbikā tradition agrees with Siddha medicine that the physical structures of the universe (macrocosm) and humans (microcosm) are built from Five Elements: Nilam (Earth), Nìr (Water), Tì (Fire), Kātru (Air) and Vin (Sky). These names denote the properties of the elements that are present in different proportions in all living beings and non-living entities. It is believed that various tissues and organs of the body are a combination of these elements (Thas 2008, p. 26).

The Lalitāmbikā adepts were told that in additional meditations, usually performed once a week, the cakras should also be imagined as being guarded by their patron deities and connected with bodily tissues or organs. The basic scheme of those meditations can be presented in the following manner:

$$
\begin{aligned}
& \bar{A} j \tilde{n} \bar{a}-\text { mind-cartilage-Hākin } \bar{\imath} \\
& \text { Viśuddha-space-skin-Dākin̄̄ } \\
& \text { Anāhata,-air-blood-Rākin̄̄ } \\
& \text { Manipūra-fire-muscles-Lākinī } \\
& \text { Svādhișthāna-water-fat-Kākin̄ } \\
& \text { Mūlādhāra-earth-bones-Śākin̄̄ }
\end{aligned}
$$

During these meditations, adepts were instructed to move their awareness into their organs, bones and tissues, and feel the inner energy flowing inside them eradicating disease. However, even though Swami restructured the teaching methods and substituted complex rituals with meditative exercises, the practice is still rooted in the textual tradition of Śrīvidyā. For instance, the association of patron goddesses with dhātu is a dogma also found in Paraśurāma Kalpasūtra sutra (7.28) in a section called dhätunāthayajanam-the veneration of the dhātus. The deities associated with cakras in this meditation are also invoked in the same context in other Tantric texts like Rudrāyāmala Tantra (White 2003, pp. 221-29).

On the final day of the training camp, every adept was formally initiated into the tradition and tested on their ability to perform a fully-fledged Śrīcakra ritual. Their meditations and rituals were observed by the Swami, who later individually instructed the 
adepts on further practice, which included meditation and rituals, but also health-oriented visualizations and protective chants.

\subsection{The Goddess: Poison and the Remedy}

As this paper has tried to indicate in the previous sections, the spiritual practices of Samayācāra are focused on protection and healing. This is directly stated in a temple leaflet given to the adept attending the Navaratri workshop, which introduced the temple as a "Śrīvidyā wellness centre", and further stated:

Śrividyā promotes a holistic approach to life-it is an inner journey to realize the light of Brahmajñāna and refrain from causing harm to other beings". "Goddess Ambika [Mother] is the disease for all those who don't realize that everything is Brahman, and she is also the medicine that cures the disease [i.e., ignorance].

The final statement echoes age-old beliefs of many Indian societies, which considered plagues or smallpox epidemics as a coming of the goddess (Stewart 1995). In Kerala and Tamilnadu, smallpox was believed to be an expression of divine power and the goddess herself. While many shrines of the Goddess of Smallpox and Chickenpox can be found in villages across India, in South India, contracting the disease was considered to be a blessing of the Goddess Vasūri (Nair 2019, pp. 361-63). The statement about the Goddess being both poison and cure attained a new meaning in 2020, when the pandemic started: the Tantric practitioners attempted to overcome the fear of the unknown disease by interpreting the pandemic situation as one of the multiple faces of the Goddess, who is the only reality. Furthermore, on 5 February 2020, the temple organized online mass chanting of the mahāmrtyuñjaya mantra to provide relief for all people affected by COVID-19. The chanting, with volunteers joining online from around the world, lasted for a month and was concluded with prayers and blessings of the Swami. The event also marked a new stage of temple life, as it began to provide its services online; since the beginning of the pandemic, the temple has organized e-workshops and provided online streaming of rituals and other spiritual events.

\section{Conclusions}

According to the teachings of the Lalitāmbika temple, the recognition of the nonduality of the universe is therefore a prerequisite for anyone who wants to be healed. In the words of the Swami, the healing provided at the temple is a spark that initiates a spiritual change in human life: it neutralizes people's karmic blocks and negative thought patterns, cleanses cakras, and sets them on their journey toward liberation. Samayācāra Śrīvidyā of the Lalitāmbikā temple is also an eclectic school of spiritual practice that does not shy away from incorporating elements of astrology and Āyurveda.

The present study has also tried to show how various forms of embodiment and healing define the practice of Samayācāra Śrīvidyā of the Lalitāmbikā temple. Defining embodied spirituality, Trousdale (2013, pp. 23-24) indicates that many Asian, religious traditions consider the human body as a tool for generating spiritual powers and a vehicle for liberation. Samayācāra Śrīvidyā subscribes to this philosophy and prescribes various techniques that allow an adept to divinize their body. The temple itself is an embodiment of the tradition that goes back to the ancient sages. The guru of the Samayācāra Śrīvidyā represents and embodies the lineage of teachers who have taught the sacred doctrine to the deserving students. Adepts who follow the tradition are on a quest to understand the spiritual reality and to experience the non-dual state. To attain this state, they identify themselves with the goddess and her representations (śricakra and mantra); they become an abode of the divine. Hence, Samayācāra Śrīvidyā practices lead to an experience of simultaneous immanence and transcendence of the divine.

As this paper has tried to indicate, the Samayācāra practices taught in the Lalitāmbikā temple are health-oriented programs and the temple integrates spirituality with various forms of healing activities and social work. In recent years, the temple established a nongovernmental organization (NGO) called the Śrī Lalitāmbikā Trust, which supports the 
underprivileged citizens of nearby villages by way of providing food and educational and medical aids. The trust also introduced a "Can Cure" project that supports cancer patients and oncological departments. Moreover, it sponsors medical camps and cooperates with local hospitals, providing yoga and meditation sessions.

Seligman (2010) observed that mystical traditions offer "healing practices that simultaneously address the cognitive-discursive and embodied aspects of self". These systems contain an integrative religious ideology and initiatory rites that aim to heal the disrupted selves. They attempt to help a traumatized individual through both "embodied and discursive practices that reinforce one another in the process". Similarly, in the Samayācāra Lalitāmbikā tradition, Tantric rites, initiations and meditations are employed to help adepts in their quest for wholeness and to eradicate physical and mental pains rooted in the belief of duality. In other words, Samayācāra of the Lalitāmbikā temple is a Śrīvidyā cult that defines itself as a healing tradition with a holistic approach to life.

Funding: The research received funding from Hainan University, research fund RZ2100001144.

Institutional Review Board Statement: Not applicable.

Informed Consent Statement: Not applicable.

Data Availability Statement: Not applicable.

Acknowledgments: I would like to thank Swami Jagadatmananda Saraswati and his disciples for all their help with this research project. Additionally, I would like to thank Monika Turska for her drawings included in this paper.

Conflicts of Interest: The author declares no conflict of interest.

\section{Notes}

1 See also (Nichter and Nichter 1996) on the language of illness in medical anthropology and construction of an illness taxonomy in South Asia.

2 I use the term "healing practices" to refer to a variety of mediations, rites, and visualizations. Many Tantric practitioners use the term kriya (an act) to refer to these spiritual remedies and the name connotes the necessity of such practices and their instantaneous effects. See Sax (2010, p. 4) for similar observations on kārya and devakārya, in the context of ritualism and ritual efficiency.

3 The goddess of the tradition is invoked with many names, but as the temple name indicates, she is praised as Lalitā (the Playful One) and Ambikā (Mother). The epithet "Lalitā" indicates her nature-the dynamics of life and the world that appears to be in a constant flux are believed to be the effects of her divine play. However, she is also a protective mother for those who follow her tradition.

4 A few years after our first meeting, Swami obtained Vedānta Saṃnyāsa Dīkṣa from Arsha Vidya Gurukula, an initiation into the ascetic order of Vedānta, and received a new name-Swami Jagadatmananda Saraswati.

5 This paper is based on data from my field research in Tamilnadu and Kerala. The interviews with the Swami and other Tantric practitioners were conducted during my multiple visits to the Lalitāmbikā temple in the years 2012-2019.

6 On history, legends, and pilgrimages to the Ayyapan temple, see also (Daniel 1984).

7 Slouber (2017, p. 107) indicates that Tripurasundarī literature abounds in references to healing and incorporates the cult of the Gāruḍa goddesses, known for their ability to heal poison and drive away snakes.

8 Fisher (2012, p. 76) observes that while in Vedānta, upāsana refers to a meditative practice aimed at the realization of Brahmajūāna, in Vedantaized Śrīvidyā, upāsanā is more than meditation or visualization—the term referring to the entire Śrīvidyā ritualism.

9 In the final stage of meditation, the advanced practitioners of Samayācāra Śrīvidyā mentally reach the Tenth Centre, a secret cakra known also as vajra cakra, where they experience the "ultimate bliss of non-duality". Interestingly, the location of vajra cakra is the same as $\bar{a} j \tilde{n} \bar{a}$ cakra but it is accessible only after all other cakras are fully activated.

10 The correspondence between the cakras of the yogic body and the āvarana are also discussed in the authoritative texts of Srīvidyā for instance Yoginīhṛdaya (2.8) (Padoux and Roger-Orphe 2013). However, the Samayācāra tradition of the Lalitāmbikā temple simplifies the meditative practices that focus on identifying adepts' bodies with the enclosures of Śrīcakra.

11 In other Śrīvidyā sects, there are different sets of bodily cakras that are to be visualized and contemplated. For instance, Urban (1997, pp. 20-21) mentions "nine energy centers or cakras which run along the spine from the genitals to the top of the head (the mūlādhāra [groin], the svādhișthāna [genitals], the maṇipūra [navel], the anāhata [stomach], the viśuddhī [neck], the lambikā [mouth], the $\bar{a} j \tilde{n} \bar{a}$ [eye brows], the sahasrāra [the crown] and the kulasahasra". 
In this respect, it is worth quoting Urban (1997, p. 20), who calls śrīcakra a "cult-o-gram or sociogram-an emblem of the divine power of the Guru".

13 Śrīcakra ritual is performed with flower and food offerings for the deities of its nine enclosures. In the full-fledged Śrīcakra $p \bar{u} j \bar{a}$, Śrīvidyā mantras and nine secret $m u d r \bar{a} s$ are used to establish an intimate connection between an adept and the divine. Those ritual acts are preceded by rites of adoration for Śiva, Viṣnu and the Guardians of the Directions (Lokapāla). The daily observances at Lalitāmbikā temple include also mutțarukal, a ritual of coconut breaking that is performed to remove spiritual obstacles. Devotees may also request Śrī Guru Bhagavān Prārthana—prayers and rituals for Dakṣināmūrti. There is also a special ritual called Śrī Visnu Durgā Prārthana, a lamp offering performed for women suffering from physical or mental problems. The priests of Lalitāmbikā temple perform also special rituals (naimittika) on auspicious occasions. Hence, for instance, Śrī Kāmeśvara Pradoșa Prārthana, an abhișeka for Śiva, is performed during the pradoșa time to remove sins and lead one towards liberation.

Interestingly, while many Śrīvidyā practitioners in South India invoke the guruparamparā with the following prayers:om aim hrị̣̄ śrìm hasakhaphreṃ hasarakșamalavaraya ūm sahakhaphrem sahakṣamalavarayaūm (Hanneder 2017, p. 233), in the Lalitāmbikā temple, the usual practice is to repeat trice the following prayer: Aị̣kāra-hrīmkāra-rahasya-yukta-Śrīmkāra-güdhārtha-mahāvibhütyā, Omkāara-marma-pratipādinībhyām Namo namah śrīgurupādukābhyah I Salutations to the pāduka (sandals) of guru, which contain the secret of aim and hrim and the glory of śrim and which expound the mystery of Om. I I Even though both prayers indicate the importance of Śrīvidyā tritari (aim-hrīm-śrīm), a formula that opens many mantras of the tradition, the prayer of Lalitāmbikā ascribes the three syllables to the qualities of a guru.

15 Most of these mantras are various forms of gāyatrī mantras (Hatcher 2019). This, in turn, echoes the Bhāskararāya notion that the main Śrīvidyā mantra is a Tantric version of Vedic gāyatrī. This ultimate unity of Vedic and Tantric gāyatrū is supposed to be one of the secrets revealed through the practice of Samayācāra Śrīvidyā.

16 Paraśurāma Kalpasūtra refers to the highest cakra by various names, such as: brahmabila or dvādaśānta: "The first two mentioned sometimes refer to the fontanel as a separate body place (maybe not a cakra in the proper sense), and sometimes they are identified with the Thousand-petaled Lotus" (Wilke 2011, p. 146).

17 Samuel (2012, p. 278) observes that there are multiple applications of prānāyanma and, in the process of controlling the internal flows of prāna, an adept might also be able to direct or channel their emotions.

18 Many lectures conducted at the Lalitāmbikā temple were devoted to the esoteric correspondences between the stotra and mantras of Śrividyā. The various names of the goddess were, according to the Swami's interpretation, either allusions to, or codified versions of, the main mantras.

19 Similarly, the Jñannārnava-tantra elaborates on the powers of the same three syllables, stating that one who chants them will charm the Three Worlds (2.10-13).

20 The practice is also alluded to at the very start of Śricakra-nyasa, a short treatise preserved in the form of a palm-leaf manuscript in the Trippunithura Manuscript Library, Kerala. There, an adept is instructed to visualize their body in the form of a central dot of Śrīcakra and meditate upon it being burnt like in the flames of the Fire of Time (Kala-agni) and inscribed with phonemes of the Sanskrit alphabet starting with "ka" and "ga":cintayedādau bījam śrīcakrarūpinaṃkāgādyākāranirmmuktam joalalkkālāgnisannibham iti sā śarìram dhyātvā

21 Similarly, in his study on secret societies and Tantra, Urban (1997, p. 17) observes that "after an initiation the adept's own exoteric self is destroyed and put to death; symbolically, his ordinary physical body is dissolved, while at the same time, the ordinary boundaries of the 'social body' are also transgressed".

22 Apart from above-mentioned rituals and daily prayers, the temple routines include also various homas (fire oblations) that can be requested by the devotees. Thus, Mahā-ganapati homa is performed to clear the obstacles before other rituals and Sudarśana homa is performed to protect one from enemies and evil influences. In the temple one may also find idols of Ten Great Goddesses (Daśamahāvidyā) installed near the main altar and worshipped along with the main deity_Lalitāmbikā. The idols are daily cleaned, anointed, and pleased with garlands of flowers, and lighting of oil lamps (nirañjana). The Daśamahāvidyā are believed to be the representations of the main goddess and their various attributes are also visualized during additional meditations.

In Śrī Tripurārahasyam Māhātmyakhandam (2011) readers can find exact locations of those powers on the meru, as per the Śrīvidyā tradition.

24 Additionally, Wilke (2012, p. 40) notes that in the Paraśurāma Kalpasūtra tradition the Vedic customs related to the worship of the sun with offerings and chanting of the gayatri mantra are combined with Tantric rites that include meditating on one's guru and the goddess in the brahmarandhra cakra and visualizing a nectar of immortality (amrta) flowing down from that cakra and purifying the whole body.

A similar statement can be found in Vāmakeśvarīmata 1.11.

An interesting analogy can be found in Ramaswamy (1997) discussion on the feminization of Tamil language. Ramaswamy (1997, p. 121) observes that "devotees may empower their language by drawing upon three different models of femininity an all-powerful goddess, a compassionate but endangered mother, and a desirable but unattainable maiden". 
of the notion of magic. Healing, therefore, was also ruled by planetary energies that could be deployed through the use of sympathetic magic" (Leopardi 2014, p. 483).

Additionally, Saraf (1970, p. 966) indicates that "the Hindu complex of worship that involves an interplay of the three elements and regards all the three as one- the devatā who is the object of worship, the mantra which the devotee pursues in his sādhanā, and the guru".

29 On the other hand, Trawick (1992, p. 148) observes that in South India, practitioners of Siddha medicine "have sought and found their roots in the only other major indigenous science of the body besides Ayurveda: Tantric yoga".

\section{References}

\section{Primary Sources}

Lalitāsahasranāma (of the second part of Brahmāṇḍapurāṇa) with the commentary Saubhāgya Bhāskara Bhāṣya of Bhāskararāya. 1919. revised by Wasudev Laxman Shastri Pansikar, Bombay: Pandurang Jawaji.

Íśvara-pratyabhijñā-kārikā, of Utpaladeva: Verses on the recognition of the Lord, translation with commentary, B. N. Pandit (transl.), Lise F. Vail (Editor), New Delhi: Motilal Banarsidass.

Jñānārṇava-tantra, Muktabodha Indological Research Institute, digital library. Available online: www.muktabodha.org (accessed on 15 May 2021).

Paraśurāmakalpasūtra. Available online: http://gretil.sub.unigoettingen.de/gretil/1_sanskr/4_rellit/saiva/paraksau.htm (accessed on 1 January 2020).

Śrīcakranyāsaṃ prakāravuṃ tamilil viṣnustuti mantranaḷụ̣ Mss.740, Manuscript Library of Trippunithura College.

Śivasamhitā. 2007. Mallinson, J. (ed.) New York.

Śrī Tripurārahasyam Māhātmyakhanḍam. 2011. Sanskrit text and English translation by T. B. Lakshmana Rao. Bengaluru: Sri Kailasamanidweepa.

Vāmakeśvarīmata, edited by Michael Magee, Prachya Prakashan: Varanasi 2005.

Varivasyārahasya and Its Commentary Prakāśa by Śr̄̄ Bhāskararāya Makhin, ed. Pandit S. Subrahmanya Sastri, Adyar Library Publication: Chennai 2000.

\section{Secondary Sources}

Bafna, Sonit. 2000. On the Idea of the Mandala as a Governing Device in Indian Architectural Tradition. Journal of the Society of Architectural Historians 59: 26-49. [CrossRef]

Baumer, Bettina. 1994. The Rajarani Temple Re-indentified. India International Centre Quarterly 21: 125-32.

Bowden, Michael. 2017. Goddess and the Guru: A Spiritual Biography of Sri Amritananda Natha Saraswati. Providence: Parallel Press.

Brooks, Douglas. 1992. Auspicious Wisdom: The Texts and Traditions of Śrīvidyā Śäkta Tantrism in South India. New York: The University of New York Press.

Coward, Harold. 2008. The Perfectibility of Human Nature in Eastern and Western Thought. New York: State of New York University Press. Daniel, Valentine E. 1984. Fluid Signs: Being a Person the Tamil Way. Berkeley: University of California Press.

Dempsey, Corinne. 2006. The Goddess Lives in Upstate New York: Breaking Convention and Making Home at a North American Hindu Temple. Oxford: Oxford University Press.

Eliade, Mircea. 1987. The Sacred and the Profane: The Nature of Religion. New York: Harcourt Brace Jovanovich.

Farah, Jindani, and Guru Fatha Singh Khalsa. 2015. A Journey to Embodied Healing: Yoga as a Treatment for Post-Traumatic Stress Disorder. Journal of Religion E Spirituality in Social Work: Social Thought 34: 394-413. [CrossRef]

Fields, Gregory. 1961. Religious Therapeutics: Body and Health in Yoga, Ayurveda, and Tantra. New York: SUNY Press.

Fisher, Elaine. 2012. 'Just Like Kālidāsa': The Śākta Intellectuals of Seventeenth-Century South India. The Journal of Hindu Studies 5: 172-92. [CrossRef]

Golovkova, Anna. 2019. From Worldly Powers to Jīvanmukti: Ritual and Soteriology in the Early Tantras of the Cult of Tripurasundarī. Journal of Hindu Studies 12: 103-26. [CrossRef]

Golovkova, Anna. 2020. The Forgotten Consort: The Goddess and Kāmadeva in the Early Worship of Tripurasundarī. International Journal of Hindu Studies 24: 1-20. [CrossRef]

Hanneder, Jürgen. 2017. Pre-modern Sanskrit Authors, Editors and Readers: Material, Textual, and Historical Investigations. In Indic Manuscript Cultures through the Ages. Edited by Vincenzo Vergiani, Daniele Cuneo and Camillo Alessio Formigatti. Berlin and Boston: De Gruyter.

Hatcher, Brian. A. 2019. Rekindling the Gāyatrī Mantra: Rabindranath Tagore and "Our Veda". International Journal of Hindu Studies 23: 1-20. [CrossRef]

Higgins, Charlotte. 2018. Red Thread: On Mazes and Labyrinths, kindle ed. London: Jonathan Cape.

Janzen, John M. 1992. Ngoma. Discourses of healing in Central and Southern Africa. Berkeley: University of California Press.

Karasinski, Maciej. 2020. A Goddess Who Unites and Empowers: Śrīvidyā as a Link Between Tantric Traditions of Modern KeralaSome Considerations. Journal of Indian Philosophy 48: 541-63. [CrossRef]

Khanna, Madhu. 2016. Yantra and Cakra in Tantric Meditation. In Asian Traditions of Meditation. Edited by Halvor Eifring. Honolulu: University of Hawai'i Press, pp. 71-92. 
Kiil, Mona Anita, and Anita Salamonsen. 2013. Embodied health practices: The use of Traditional Healing and Conventional Medicine in a North Norwegian Community. Academic Journal of Interdisciplinary Studies 2: 483-88. [CrossRef]

Lawrence, David. 1998. The Mythico-Ritual Syntax of Omnipotence. Philosophy East and West 48: 592-622. [CrossRef]

Leopardi, Liliana. 2014. Magic Healing and Embodied Sensory Faculties in Camillo Leonardi's Speculum Lapidum. In Mental Health, Spirituality, and Religion in the Middle Ages and Early Modern Age. Edited by Albrecht Classen. Berlin: De Gruyter. [CrossRef]

Lidke, Jeffrey. 2016. The Potential of the Bi-Directional Gaze: A Call for Neuroscientific Research on the Simultaneous Activation of the Sympathetic and Parasympathetic Nervous Systems through Tantric Practice. Religions 7: 132. [CrossRef]

Lidke, Jeffrey. 2017. The Goddess within and beyond the Three Cities: Śäkta Tantra and the Paradox of Power in Nepāla Maṇdala. New Delhi: D. K. Printworld.

Mann, Richard. 1984. The Light of Consciousness_Explorations in Transpersonal Psychology. New York: State Univ of New York Press.

Muller-Ortega, Paul. 1997. The Triadic Heart of Śiva. New Delhi: Motilal Banarasidass.

Nair, Aparna. 2019. Vaccinating against Vasoori: Eradicating smallpox in the 'model' princely state of Travancore, 1804-1946. The Indian Economic \& Social History Review 56: 361-86.

Nichter, Mark, and Mimi Nichter. 1996. Anthropology and International Health: Asian Case Studies. Amsterdam: Gordon and Breach.

Osella, Filippo, and Caroline Osella. 2003. Ayyappan Saranam: Masculinity and the Sabarimala Pilgrimage in Kerala. The Journal of the Royal Anthropological Institute 9: 729-54. [CrossRef]

Padoux, André. 2017. Hindu Tantric World: An Overview. London: University of Chicago Press.

Padoux, André, and Jeanty Roger-Orphe. 2013. The Heart of the Yogini: Yoginihrdaya, a Sanskrit Tantric Treatise. Oxford: Oxford University Press. Rama, Swami. 2007. Choosing a Path. Pennsylvania: Himalayan Institute Press.

Ramaswamy, Sumathi. 1997. Passions of the Tongue: Language Devotion in Tamil India, 1891-1970 Studies on the History of Society and Culture. Berkeley: University of California Press.

Reich, James. 2020. Poetry and the Play of the Goddess: Theology in Jayaratha's Alaṃkāravimarśinī. Journal of Indian Philosophy 48: 665-74. [CrossRef]

Samuel, Geoffrey Brian. 2012. Amitāyus and the development of tantric practices for longevity and health in Tibet. In Transformations and Transfer of Tantra in Asia and beyond, Religion and Society. Edited by Keul Istvan. Boston: Walter De Gruyter.

Saraf, Samarendra. 1970. The Trichotomous Theme: A Ritual Category in Hindu Culture. Anthropos 65: 948-72.

Sax, William. 2010. Ritual and Problem of Efficacy. In The Problem of Ritual Efficacy. Edited by Sax William, Quack Johannes and Jan Weinhold. Oxford: Oxford University Press.

Seligman, Rebecca. 2010. Unmaking and Making of Self: Embodied Suffering and Mind-Body Healing in Brazilian Candomble. ETHOS 38: 297-320. [CrossRef]

Shulman, David. 1991. The Yogi's Human Self: Tayumanavar in the Tamil Mystical Tradition. Religion 21: 51-72. [CrossRef]

Simmons, Caleb, and Moumita Sen. 2018. Introduction: The Movement of Navaratri. In Nine Nights of the Goddess The Navaratri Festival in South Asia. Edited by Caleb Simmons, Moumita Sen and Hillary Rodrigues. New York: Suny Press.

Slouber, Michael. 2017. Early Tantric Medicine: Snakebite, Mantras, and Healing in the Garuda Tantras. Oxford: Oxford University Press.

Spradley, James P. 1980. Participant Observation. Orlando: Harcourt College Publishers.

Stewart, Tony. 1995. Encountering the Smallpox Goddess: The Auspicious Song of Sítalā. In Religions of India in Practice. Edited by Donald S. Lopez. Princeton: Princeton University Press, pp. 389-98.

Thas, Joseph. 2008. Siddha Medicine-Background and principles and the application for skin diseases. Clinics in Dermatology 26: 62-78. [CrossRef]

Timalsina, Sthaneshwar. 2012a. Reconstructing the Tantric Body: Elements of the Symbolism of Body in the Monistic Kaula and Trika Tantric Traditions. International Journal of Hindu Studies 16: 57-91. [CrossRef]

Timalsina, Sthaneshwar. 2012b. Body, Self, and Healing in Tantric Ritual Paradigm. The Journal of Hindu Studies 5: 30-52. [CrossRef]

Timalsina, Sthaneshwar. 2015. Tantric Visual Culture: A Cognitive Approach. London and New York: Routledge.

Timalsina, Sthaneshwar. 2020. Aham, Subjectivity, and the Ego: Engaging the Philosophy of Abhinavagupta. Journal of Indian Philosophy 48: 767-89. [CrossRef]

Trawick, Margaret. 1992. Death and Nurturance in Indian Systems of Healing. In Paths to Asian Medical Knowledge Comparative Studies of Health Systems and Medical Care. Edited by Charles Leslie and Allan Young. Berkeley: University of California Press, pp. 129-59.

Trousdale, Ann. 2013. Embodied spirituality. International Journal of Children's Spirituality 18: 18-29. [CrossRef]

Tulasi, Srinivas. 2018. The Cow in the Elevator: An Anthropology of Wonder. Durham and London: Duke University Press.

Ulland, Dagfinn. 2012. Embodied Spirituality. Archive for the Psychology of Religion 34: 83-104. [CrossRef]

Urban, Hugh. 1997. Elitism and Esotericism: Strategies of Secrecy and Power in South Indian Tantra and French Freemasonry. Numen 44: 1-38. [CrossRef]

Van Skyhawk, Hugh. 2008. Cleansing and Renewing the Field for Another Year: Processions between Holy Places as Networks of Reflexivity. Zeitschrift der Deutschen Morgenländischen Gesellschaft 158: 353-70.

Wallis, Christopher. 2014. To Enter, to Be Entered, to Merge: The Role of Religious Experience in the Traditions of Tantric Shaivism. Ph.D. dissertation, University of California, Berkeley, CA, USA.

Weiss, Richard. 2009. Recipes for Immortality: Healing, Religion, and Community in South India. Oxford: Oxford University Press.

White, David Gordon. 2003. Kiss of the Yogini. Chicago: University of Chicago Press. 
Wilke, Annette. 2005. A New Theology of Bliss: “Vedāntization" of Tantra and "Tāntricization" of Advaita Vedānta in the Lalitātriśatibhāsya. In Sāmarasya: Studies in Indian Arts, Philosophy, and Interreligious Dialogue. Edited by Sadananda Das and Ernst Fürlinger. New Delhi: D. K. Printworld, pp. 139-55.

Wilke, Annette. 2011. Negotiating Tantra and Veda in the Paraśurāma-Kalpa Tradition. In Negotiating Rites. Edited by Ute Husken and Frank Neubert. Oxford: Oxford University Press.

Wilke, Annette. 2012. Recoding the Natural and Animating the Imaginary Kaula Body-practices in the Paraśurāma-Kalpasūtra, Ritual Transfers, and the Politics of Representation. In Transformation and Transfer of Tantra in Asia and beyond. Edited by Istvan Keul. Berlin: De Gruyter. 